\title{
FREKUENSI KEMOTERAPI DAPAT MENURUNKAN ASUPAN ZAT GIZI DAN STATUS GIZI PADA PASIEN KANKER PAYUDARA DI RUANG PERAWATAN KELAS III RSUP SANGLAH DENPASAR
}

\author{
Ni Nyoman Astika Dewi ${ }^{1}$, I Made Dony Aryawan ${ }^{2}$ \\ ${ }^{1}$ Jurusan Gizi Poltekkes Denpasar, ${ }^{2}$ Instalasi Gizi RSUP Sanglah Denpasar \\ astikadewininyoman@yahoo.co.id
}

\begin{abstract}
Chemotherapy has contributed to the occurrence of malnutrition and influence nutrient intake and nutritional status. This study was conducted to determine the effect of chemotherapy on the frequency decrease nutrient intake and nutritional status in breast cancer patients in the treatment room class III Sanglah Hospital. This type of research is observational with cross sectional approach. How sampling is done by using consecutive sampling technique, the sample size of 40 people. Based on the research results through statistical test known there was a significant relationship between the frequency of chemotherapy with energy intake. There is a significant relationship between the frequency of chemotherapy with protein intake. There was no significant relationship between the frequency of chemotherapy with fat intake. There is a significant relationship between the frequency of chemotherapy with carbohydrate intake. There is no significant relationship between the frequency of chemotherapy by the intake of Vitamin A. There is no significant correlation between the frequency of chemotherapy with vitamin $C$. There is a significant relationship between the frequency of chemotherapy by the intake of vitamin $E$. There was no significant relationship between the frequency of chemotherapy in breast cancer patients nutritional status. Need to do further research on other factors that influence nutrient intake and nutritional status in patients with breast cancer and improving patient education, especially in change foods in order to create optimal nutritional status of patients.
\end{abstract}

Keywords : frequency of chemoteraphy; nutrient intake; nutritional status

\begin{abstract}
Abstrak. Kemoterapi mempunyai kontribusi pada terjadinya malnutrisi serta mempengaruhi asupan zat gizi dan status gizi. Penelitian ini dilakukan untuk mengetahui efek frekuensi kemoterapi terhadap penurunan asupan zat gizi dan status gizi pada pasien kanker payudara yang di ruang perawatan kelas III RSUP Sanglah Denpasar. Jenis penelitian ini adalah penelitian observasional dengan pendekatan crossectional. Cara pengambilan sampel dilakukan dengan menggunakan teknik consecutive sampling, jumlah sampel 40 orang. Berdasarkan hasil penelitian melalui uji statistika diketahui ada hubungan bermakna antara frekuensi kemoterapi dengan asupan energi. Terdapat hubungan bermakna antara frekuensi kemoterapi dengan asupan protein. Tidak terdapat hubungan bermakna antara frekuensi kemoterapi dengan asupan lemak. Terdapat hubungan bermakna antara frekuensi kemoterapi dengan asupan karbohidrat. Tidak ada hubungan bermakna antara frekuensi kemoterapi dengan asupan Vitamin A. Tidak ada hubungan bermakna antara frekuensi kemoterapi dengan asupan vitamin C. Terdapat hubungan bermakna antara frekuensi kemoterapi dengan asupan vitamin E. Tidak ada hubungan bermakna antara frekuensi kemoterapi dengan status gizi pasien kanker payudara. Perlu dilakukan penelitian lanjutan tentang faktor - faktor lain yang berpengaruh terhadap asupan gizi dan status gizi pasien kanker payudara dan meningkatkan pengetahuan pasien terutama dalam pemillihan bahan makanan agar tercipta keadaan gizi pasien yang optimal.
\end{abstract}

Kata Kunci : frekuensi kemoterapi, asupan gizi, status gizi 


\section{Pendahuluan}

Kanker atau neoplasma ganas adalah penyakit yang ditandai dengan kelainan siklus sel khas yang menimbulkan kemampuan sel untuk tumbuh tidak terkendali (pembelahan sel melebihi batas normal), menyerang jaringan biologis di dekatnya dan bermigrasi ke jaringan tubuh yang lain melalui sirkulasi darah atau sistem limfatik yang disebut metastasis. Kanker merupakan pertumbuhan jaringan abnormal pada tubuh dan dapat menyebabkan efek merugikan yang berat bagi status gizi. Tidak hanya sel kanker yang mengambil zat gizi dari tubuh pasien tetapi pengobatan dan akibat fisiologis dari kanker dapat mengganggu dalam mempertahankan kecukupan gizi. ${ }^{1}$

Angka kematian akibat kanker payudara mencapai 5 juta pada wanita. Data terakhir menunjukkan bahwa kematian akibat kanker payudara pada wanita menunjukkan angka ke-2 tertinggi penyebab kematian setelah kanker rahim. ${ }^{2}$

Berdasarkan data kejadian kanker di Ruang Angsoka RSUP Sanglah Denpasar pada bulan Januari 2013 adalah 64 kasus, Februari 2013 sebanyak 90 kasus, Maret 2013 terdapat 82 kasus dan pada bulan April 2013 terjadi 99 kasus. Sedangkan kunjungan pasien kanker payudara pada bulan April terdapat 40 kasus dan yang menjalani kemoterapi sebanyak 18 kasus. ${ }^{3}$
Kemoterapi mempunyai kontribusi pada terjadinya malnutrisi dengan berbagai sebab antara lain mual, muntah, stomatitis atau sariawan, gangguan saluran pencernaan dan penurunan nafsu makan. Kekerapan gejala mual dan muntah pada penggunaan kemoterapi tergantung pada jenis obat kemoterapi, dosis dan jadwal pemberian. Sekitar 70-80 \% pasien yang mendapat kemoterapi akan merasakan mual dan muntah. Keadaan ini akan mempengaruhi asupan zat gizi dan status gizi. Zat gizi yang mempengaruhi status gizi yaitu energi, protein, lemak dan karbohidrat. Sedangkan mikro nutrient yang berperanan dalam pencegahan perkembangan sel-sel kanker antara lain Vitamin A, Vitamin C, dan Vitamin E. ${ }^{\mathbf{4}}$

Penelitian yang sudah pernah dilakukan oleh Setyaningrum ${ }^{5}$ pada tahun 2009 tentang hubungan kemoterapi dengan asupan energi protein dan status gizi pada pasien Leukemia Limfoblastik Akut (LLA) di RSUP dr. Sardjito Yogyakarta. Penelitian menunjukkan hasil bahwa terdapat hubungan antara kemoterapi dengan asupan energi dan status gizi pada pasien serta tidak ada hubungan antara kemoterapi dengan asupan protein.

Penelitian Rahajeng tentang tingkat kecukupan energi, protein dan status gizi pasien pra dan pasca operasi kanker payudara di RSUP Dr. Karyadi Semarang. 
Hasil penelitian menunjukkan terdapat penurunan tingkat kecukupan energi, protein dan status gizi berdasarkan pemeriksaan albumin antara pra operasi dengan pasca operasi pada subjek dengan kemoterapi dan tanpa kemoterapi. ${ }^{6}$

Penelitian Mistirahayu tentang pengaruh kemoterapi terhadap penurunan status nutrisi pada pasien kanker di RS Dr. Saiful Anwar Malang, yang hasilnya menunjukkan bahwa ada pengaruh kemoterapi terhadap penurunan status nutrisi pada penderita kanker. ${ }^{7}$

Penelitian ini bertujuan untuk mengetahui frekuensi kemoterapi berpotensi menurunkan asupan zat gizi makro dan mikro serta status gizi pada pasien kanker payudara di ruang perawatan kelas III RSUP Sanglah Denpasar.

\section{Metode}

Jenis penelitian ini merupakan penelitian observasional dengan pendekatan crossectional. Tempat penelitian di ruang perawatan kelas III RSUP Sanglah Denpasar. Populasi penelitian adalah semua pasien Kanker Payudara yang dirawat di ruang perawatan kelas III RSUP Sanglah
Denpasar. Sampel penelitian adalah semua pasien Kanker Payudara yang dirawat di ruang perawatan kelas III dan menjalani kemoterapi di RSUP Sanglah Denpasar. Cara pengambilan sampel dilakukan dengan menggunakan teknik consecutive sampling, yaitu sampel yang memenuhi kriteria penelitian dimasukkan ke dalam penelitian sehingga jumlah sampel yang diperlukan terpenuhi. Jumlah sampel adalah 40 orang.

Teknik pengolahan data dengan menggunakan analisis statistic for windows dengan uji chi-square dengan batas kemaknaan statistik (p-value) 0,05 untuk mengetahui ada hubungan bermakna (signifikan) antara variable bebas dan variable tergantung. Jika $p$-value $\leq 0,05$ maka hasil hitungan statistik bermakna sebaliknya jika $p$-value $>0,05$ berarti hasilnya tidak bermakna.

\section{Hasil dan Pembahasan}

Subyek penelitian berjumlah 40 orang, yang dirawat di ruang kelas III RSUP Sanglah Denpasar. Karakteristik sampel meliputi jenis kelamin, umur, dan pendidikan. Semua sampel berjenis kelamin perempuan.

Tabel 1

Data Karakteristik Responden

\begin{tabular}{lccc}
\hline & Variabel & $\mathrm{N}$ & $\%$ \\
\hline Umur & & \\
- $30-49$ tahun & 27 & 67,5 \\
- $50-64$ tahun & 12 & 30,0 \\
- 65 tahun + & 1 & 2,50 \\
\hline
\end{tabular}




\begin{tabular}{lcc}
\hline Tingkat Pendidikan & & \\
- SD & 4 & 10,0 \\
- SMP & 5 & 12,5 \\
- Perguruan tinggi & 27 & 67,5 \\
\hline
\end{tabular}

Berdasarkan sebaran umur sampel diperoleh data bahwa umur sampel yang terbanyak berada pada kelompok umur 3049 tahun yaitu 27 orang $(67,5 \%)$. Sampel umur termuda adalah 33 tahun dan tertua adalah 67 tahun. Pada tingkat pendidikan, SMA sebanyak 27 orang $(67,50 \%)$.

Distribusi sampel menurut frekuensi kemoterapi dikelompokkan berdasarkan frekuensi melakukan kemoterapi dan kondisi umum yang menyertai pasien.

Kemoterapi A : Kemoterapi 1 dan 2 kali

Kemoterapi B : Kemoterapi 3 dan 4 kali

Kemoterapi C : Kemoterapi $\geq 5$ kali

Hasil penelitian menunjukkan frekuensi kemoterapi yang terbanyak pada sampel kemoterapi $\mathrm{C}$ sebanyak 18 orang $(45 \%)$.

Tabel 2

Frekuensi Kemoterapi Menurut Kelompok Umur

\begin{tabular}{|c|c|c|c|c|c|c|c|c|}
\hline \multirow{3}{*}{$\begin{array}{l}\text { Kelompok } \\
\text { Umur }\end{array}$} & \multicolumn{6}{|c|}{ Frekuensi Kemoterapi } & \multicolumn{2}{|c|}{ Jumlah } \\
\hline & \multicolumn{2}{|c|}{ A } & \multicolumn{2}{|c|}{ B } & \multicolumn{2}{|c|}{$\mathrm{C}$} & \multirow[b]{2}{*}{$\mathrm{n}$} & \multirow[b]{2}{*}{$\%$} \\
\hline & $\mathrm{n}$ & $\%$ & $\mathrm{n}$ & $\%$ & $\mathrm{n}$ & $\%$ & & \\
\hline $30-49$ & 6 & 22,2 & 8 & 29,6 & 13 & 48,1 & 27 & 67,5 \\
\hline $50-64$ & 3 & 25 & 5 & 41,6 & 4 & 33,4 & 12 & 30 \\
\hline $65+$ & 0 & 0 & 0 & 0 & 1 & 100 & 1 & 2,5 \\
\hline
\end{tabular}

Data asupan gizi pada sampel diperoleh dengan menggunakan metode Comstock setelah sampel melakukan kemoterapi dilaksanakan di ruang perawatan selama sehari. Hal ini dilakukan karena pada sampel hanya mendapatkan 1 2 hari saja perawatan pasca kemoterapi selanjutnya sampel sudah diijinkan pulang.

Hasil penelitian menunjukkan dapat diketahui bahwa sebagian besar sampel tingkat buruk (55\%) dibandingkan dengan kebutuhan. Sebagian besar tingkat asupan lemak sampel adalah berada pada tingkat buruk (72,50\%) dibandingkan dengan kebutuhan. Sedangkan tingkat asupan karbohidrat sebagian besar sampel adalah kurang dari kebutuhan (57,50\%). Distribusi sampel menurut asupan zat gizi makro meliputi energi, protein, lemak, dan karbohidrat dapat dilihat pada tabel 3. mempunyai asupan energi yang kurang dari kebutuhan (50\%). Sebagian besar tingkat asupan protein sampel adalah berada pada 
Tabel 3

Tingkat Asupan Zat Gizi Makro Pada Sampel

\begin{tabular}{|c|c|c|c|c|c|c|c|}
\hline \multirow{3}{*}{$\begin{array}{c}\text { Zat Gizi } \\
\text { Makro }\end{array}$} & \multicolumn{6}{|c|}{ Tingkat Asupan Gizi } & \multirow{3}{*}{ Jumlah } \\
\hline & \multicolumn{2}{|c|}{ Baik } & \multicolumn{2}{|c|}{ Kurang } & \multicolumn{2}{|c|}{ Buruk } & \\
\hline & $\mathrm{N}$ & $\%$ & $\mathrm{~N}$ & $\%$ & $\mathrm{n}$ & $\%$ & \\
\hline Energi & 5 & 12,50 & 20 & 50,00 & 15 & 37,50 & 40 \\
\hline Protein & 0 & 0,00 & 18 & 45,00 & 22 & 55,00 & 40 \\
\hline Lemak & 2 & 5,00 & 9 & 22,50 & 29 & 72,50 & 40 \\
\hline $\mathrm{KH}$ & 11 & 27,50 & 23 & 57,50 & 6 & 15,00 & 40 \\
\hline
\end{tabular}

Berdasarkan hasil penelitian dengan kebutuhan. Sedangkan tingkat diketahui bahwa sebagian besar tingkat asupan Vitamin A sampel adalah pada kategori baik dibandingkan dengan kebutuhan $(82,50 \%)$. Sebagian besar tingkat asupan Vitamin C sampel adalah berada asupan Vitamin E sebagian besar sampel adalah berada pada tingkat kurang $(52,50 \%)$ dibandingkan dengan kebutuhan. Distribusi sampel menurut tingkat asupan zat gizi mikro dapat dilihat pada tabel 4 . pada tingkat baik (65\%) dibandingkan

Tabel 4

Tingkat Asupan Zat Gizi Mikro Pada Sampel

\begin{tabular}{lcrrrrrr}
\hline Zat Gizi M & \multicolumn{7}{c}{ Tingkat Asupan Zat Gizi } \\
\cline { 2 - 8 } & \multicolumn{2}{c}{ Baikro } & \multicolumn{2}{c}{ Kurang } & \multicolumn{2}{c}{ Buruk } & jml \\
\hline Vitamin A & 33 & 82,50 & 7 & 1,5 & 0 & 0,0 & 40 \\
Vitamin C & 26 & 65,00 & 7 & 17,5 & 7 & 17,5 & 40 \\
Vitamin E & 2 & 5,00 & 21 & 52,5 & 17 & 42,5 & 40 \\
\hline
\end{tabular}

Tabel 5

Status Gizi Responden

\begin{tabular}{ccc}
\hline Status Gizi & N & $\%$ \\
\hline Lebih & 5 & 12,50 \\
Baik & 28 & 70,00 \\
Kurang & 7 & 17,50 \\
\hline
\end{tabular}

Berdasarkan tabel di atas dapat dilihat bahwa sebagian besar status gizi sampel berada pada status gizi baik sebanyak 28 orang (70\%). Sedangkan sampel yang mengalami malnutrisi dengan gizi lebih sebanyak 5 orang $(12,5 \%)$ dan gizi kurang sebanyak 7 orang $(17,5 \%)$.

Dari analisis Chi square dapat diketahui bahwa sampel yang menjalani kemoterapi A sebanyak 8 sampel (20\%), 
kemoterapi B sebanyak 14 sampel (35\%), sedangkan Kemoterapi C sebanyak 18 sampel (45\%). Hubungan frekuensi kemoterapi dengan asupan zat gizi sampel diteliti diuraikan menurut jenis asupan zat gizi sebagai berikut :

Hubungan frekuensi kemoterapi dengan asupan energi

Tabel 6

Distribusi Hubungan Frekuensi Kemoterapi Dengan Asupan Energi

\begin{tabular}{cccccc}
\hline \multirow{2}{*}{ Frekuensi Kemoterapi } & \multicolumn{3}{c}{ Asupan Energi } & \multirow{2}{*}{$X^{2}$} & \multirow{2}{*}{$\mathrm{p}$} \\
\cline { 2 - 4 } & Baik & Kurang & Buruk & & \\
\hline Kemoterapi A & $3(37,5 \%)$ & $5(62,5 \%)$ & $0(0 \%)$ & & \multirow{2}{*}{0,026} \\
Kemoterapi B & $2(14,3 \%)$ & $5(35,7 \%)$ & $7(50 \%)$ & \multirow{2}{*}{11,033} & \multirow{2}{*}{0,0} \\
Kemoterapi C & $0(0 \%)$ & 10 & $8(44,4 \%)$ & & \\
\hline
\end{tabular}

Berdasarkan tabel dapat diketahui bahwa sampel yang menjalani Kemoterapi A sebagian besar mempunyai asupan energi kurang dari kebutuhan sebanyak 5 orang $(62,5 \%)$. Kemoterapi B sebagian besar asupan energinya pada kategori buruk sebanyak 7 orang $(50 \%)$. Sedangkan kemoterapi C sebagian besar asupan energinya pada kategori kurang dari kebutuhan sebanyak 10 orang $(55,6 \%)$. Setelah dilakukan uji statistik hubungan frekuensi kemoterapi dengan asupan energi diperoleh nilai $\mathrm{p}$ yaitu $0,026 \quad(\mathrm{p}<0,05)$ sehingga dapat dikatakan bahwa ada hubungan bermakna antara frekuensi kemoterapi dengan asupan energi pasien kanker payudara.

Tabel 7

Distribusi Hubungan Frekuensi Kemoterapi Dengan Asupan Protein

\begin{tabular}{lcccc}
\hline Frekuensi Kemoterapi & \multicolumn{2}{c}{ Asupan Protein } & \multirow{2}{*}{$\mathrm{X}^{2}$} & \multirow{2}{*}{$\mathrm{p}$} \\
\cline { 2 - 3 } & Kurang & Buruk & & \\
\hline Kemoterapi A & $8(100 \%)$ & $0(0 \%)$ & & \\
Kemoterapi B & $6(42,9 \%)$ & $8(57,1 \%)$ & \multirow{2}{*}{13,577} & 0,001 \\
Kemoterapi C & $4(22,2 \%)$ & $14(77,8 \%)$ & & \\
\hline
\end{tabular}

Berdasarkan tabel dapat diketahui bahwa sampel yang menjalani Kemoterapi A semuanya mempunyai asupan protein kurang dari kebutuhan sebanyak 8 orang
(100\%). Kemoterapi B sebagian besar asupan proteinnya pada kategori buruk sebanyak 8 orang $(57,1 \%)$. Sedangkan kemoterapi $\mathrm{C}$ sebagian besar asupan 
proteinnya pada kategori buruk dari sehingga dapat dikatakan bahwa ada kebutuhan sebanyak 14 orang (77,8\%). hubungan bermakna antara frekuensi Setelah dilakukan uji statistik hubungan kemoterapi dengan asupan protein pasien frekuensi kemoterapi dengan asupan protein kanker payudara. diperoleh nilai $p$ yaitu $0,001 \quad(\mathrm{p}<0,05)$

Hubungan frekuensi kemoterapi dengan asupan lemak

Tabel 8

Distribusi Hubungan Frekuensi Kemoterapi Dengan Asupan Lemak

\begin{tabular}{lccccc}
\hline \multicolumn{1}{c}{ Frekuensi } & \multicolumn{3}{c}{ Asupan Lemak } & $\mathrm{X}^{2}$ & $\mathrm{p}$ \\
\cline { 2 - 4 } Kemoterapi & Baik & Kurang & Buruk & & \\
\hline Kemoterapi A & $1(12,5 \%)$ & $3(37,5 \%)$ & $4(50,0 \%)$ & & \\
Kemoterapi B & $1(7,1 \%)$ & $2(14,3 \%)$ & $11(78,6 \%)$ & 3,848 & 0,427 \\
Kemoterapi C & $0(0 \%)$ & $4(22,2 \%)$ & $14(77,8 \%)$ & & \\
\hline
\end{tabular}

Berdasarkan tabel 8 dapat diketahui bahwa sebagian besar sampel mempunyai asupan lemak yang buruk pada semua kategori frekuensi kemoterapi, dengan rincian yaitu sampel yang menjalani Kemoterapi A sebanyak 4 orang $(50,0 \%)$, Kemoterapi B sebanyak 11 orang (78,6\%), dan Kemoterapi C sebanyak 14

\section{Hubungan frekuensi kemoterapi dengan asupan karbohidrat}

Tabel 9

Distribusi Hubungan Frekuensi Kemoterapi Dengan Asupan Karbohidrat

\begin{tabular}{cccccc}
\hline \multirow{2}{*}{ Frekuensi Kemoterapi } & \multicolumn{3}{c}{ Asupan Karbohidrat } & \multirow{2}{*}{$\mathrm{X}^{2}$} & \multirow{2}{*}{$\mathrm{p}$} \\
\cline { 2 - 4 } & Baik & Kurang & Buruk & & \\
\hline Kemoterapi A & $7(87,5 \%)$ & $1(12,5 \%)$ & $0(0 \%)$ & & \multirow{2}{*}{0} \\
Kemoterapi B & $3(21,4 \%)$ & $7(50,0 \%)$ & $4(28,6 \%)$ & 21,956 & \\
Kemoterapi C & $1(5,6 \%)$ & 15 & $2(11,1 \%)$ & & \\
\hline
\end{tabular}

Berdasarkan tabel dapat diketahui bahwa sampel yang menjalani kemoterapi

A sebagian besar asupan karbohidrat pada kategori baik dibandingkan dengan 
kebutuhan sebanyak 7 orang $(87,5 \%)$. hubungan frekuensi kemoterapi dengan

Kemoterapi B sebagian besar pada kategori kurang dari kebutuhan sebanyak 7 orang (50,0\%). Sedangkan kemoterapi C sebagian besar asupan karbohidrat pada kategori kurang dari kebutuhan sebanyak 15 orang asupan karbohidrat diperoleh nilai $\mathrm{p}$ yaitu $0,000(\mathrm{p}<0,05)$ sehingga dapat dikatakan bahwa ada hubungan bermakna antara frekuensi kemoterapi dengan asupan karbohidrat pasien kanker payudara.

$(83,3 \%)$. Setelah dilakukan uji statistik

Hubungan frekuensi kemoterapi dengan asupan vitamin A

Tabel 10

Distribusi Hubungan Frekuensi Kemoterapi Dengan Asupan Vitamin A

\begin{tabular}{|c|c|c|c|c|}
\hline \multirow{2}{*}{ Frekuensi kemoterapi } & \multicolumn{2}{|c|}{ Asupan vitamin A } & \multirow{2}{*}{$X^{2}$} & \multirow{2}{*}{$\mathrm{P}$} \\
\hline & Baik & Kurang & & \\
\hline Kemoterapi A & $7(87,5 \%)$ & $1(12,5 \%)$ & & \\
\hline Kemoterapi B & $13(92,9 \%)$ & $1(7,1 \%)$ & 2,496 & 0,287 \\
\hline Kemoterapi C & $13(72,2 \%)$ & $5(27,8)$ & & \\
\hline
\end{tabular}

Berdasarkan tabel dapat diketahui bahwa sebagian besar sampel mempunyai asupan Vitamin A yang baik dibandingkan dengan kebutuhan pada semua kategori frekuensi kemoterapi, dengan rincian yaitu Kemoterapi A sebanyak 7 orang $(8,5 \%)$, Kemoterapi B sebanyak 13 orang $(92,9 \%)$, dan Kemoterapi C sebanyak 13 orang
(72,2\%). Setelah dilakukan uji statistik hubungan frekuensi kemoterapi dengan asupan Vitamin A diperoleh nilai p yaitu 0,287 ( $p>0,05)$ sehingga dapat dikatakan bahwa tidak ada hubungan bermakna antara frekuensi kemoterapi dengan asupan Vitamin A pasien kanker payudara.

\section{Hubungan frekuensi kemoterapi dengan asupan vitamin C}

Tabel 11

Distribusi Hubungan rekuensi Kemoterapi Dengan Asupan Vitamin C

\begin{tabular}{lccccc}
\hline \multicolumn{1}{c}{ Frekuensi } & \multicolumn{3}{c}{ Asupan Vitamin C } & $\mathrm{X}^{2}$ & $\mathrm{p}$ \\
\cline { 2 - 4 } Kemoterapi & Baik & Kurang & Buruk & & \\
\hline Kemoterapi A & $7(87,5 \%)$ & $1(12,5 \%)$ & $0(0 \%)$ & & \\
Kemoterapi B & $9(64,3 \%)$ & $2(14,3 \%)$ & $3(21,4 \%)$ & 3,101 & 0,541 \\
Kemoterapi C & $10(55,6 \%)$ & $3(16,6 \%)$ & $5(27,8 \%)$ & & \\
& & & & & \\
\hline
\end{tabular}


Berdasarkan tabel dapat diketahui orang (55,6\%). Setelah dilakukan uji bahwa sebagian besar sampel mempunyai statistik hubungan frekuensi kemoterapi asupan Vitamin $\mathrm{C}$ yang baik dibandingkan dengan asupan vitamin $\mathrm{C}$ diperoleh nilai $\mathrm{p}$ dengan kebutuhan pada semua kategori yaitu $0,541 \quad(p>0,05)$ sehingga dapat frekuensi kemoterapi. Sedangkan rincian- dikatakan bahwa tidak ada hubungan nya adalah Kemoterapi A sebanyak 7 orang bermakna antara frekuensi kemoterapi (87,5\%), Kemoterapi B sebanyak 9 orang dengan asupan vitamin C pada pasien $(64,3 \%)$, dan Kemoterapi C sebanyak 10 kanker payudara.

Hubungan frekuensi kemoterapi dengan asupan vitamin E

Tabel 12

Distribusi Hubungan Frekuensi Kemoterapi dengan Asupan Vitamin E

\begin{tabular}{lccccc}
\hline \multicolumn{1}{c}{ Frekuensi } & \multicolumn{3}{c}{ Asupan Vitamin E } & \multirow{2}{*}{$\mathrm{X}^{2}$} & P \\
\cline { 2 - 4 } Kemoterapi & Baik & Kurang & Buruk & & \\
\hline Kemoterapi A & $1(12,5 \%)$ & $6(75,0 \%)$ & $1(12,5 \%)$ & & \\
Kemoterapi B & $0(0 \%)$ & $4(28,5 \%)$ & $10(71,5 \%)$ & \multirow{2}{*}{14,313} & \multirow{2}{*}{0,006} \\
Kemoterapi C & $0(0 \%)$ & $3(16,7 \%)$ & $15(83,3 \%)$ & & \\
\hline
\end{tabular}

Berdasarkan tabel di atas dapat diketahui bahwa sampel yang menjalani kemoterapi A sebagian besar asupan vitamin E pada kategori kurang dari kebutuhan sebanyak 6 orang $(75,0 \%)$. Kemoterapi B sebagian besar asupan vitamin E pada kategori buruk sebanyak 10 orang $(71,5 \%)$. Sedangkan kemoterapi C sebagian besar asupan vitamin E pada kategori buruk sebanyak 15 orang $(83,3 \%)$. Setelah dilakukan uji statistik hubungan frekuensi kemoterapi dengan asupan vitamin $\mathrm{E}$ diperoleh nilai $\mathrm{p}$ yaitu 0,006 $(p<0,05)$ sehingga dapat dikatakan bahwa ada hubungan bermakna antara frekuensi kemoterapi dengan asupan vitamin E pada pasien kanker payudara. 
Hubungan frekuensi kemoterapi dengan status gizi

Tabel 13

Distribusi Hubungan Frekuensi Kemoterapi Dengan Status Gizi

\begin{tabular}{|c|c|c|c|c|c|}
\hline \multirow{2}{*}{$\begin{array}{l}\text { Frekuensi } \\
\text { Kemoterapi }\end{array}$} & \multicolumn{3}{|c|}{ Status Gizi } & \multirow[t]{2}{*}{$\mathrm{X}^{2}$} & \multirow[t]{2}{*}{$\mathrm{p}$} \\
\hline & Baik & Kurang & Lebih & & \\
\hline Kemoterapi A & $4(50,0 \%)$ & $2(25,0 \%)$ & $2(25,0 \%)$ & \multirow{3}{*}{6,530} & \multirow{3}{*}{0,165} \\
\hline Kemoterapi B & $12(85,7 \%)$ & $0(0 \%)$ & $2(14,3 \%)$ & & \\
\hline Kemoterapi C & $12(66,7 \%)$ & $5(27,7 \%)$ & $1(5,6 \%)$ & & \\
\hline
\end{tabular}

Berdasarkan Tabel 13 dapat diketahui bahwa sebagian besar sampel mempunyai status gizi baik pada semua kategori frekuensi kemoterapi. Kemoterapi A sebanyak 4 orang $(50,0 \%)$, Kemoterapi B sebanyak 12 orang $(85,7 \%)$, dan Kemoterapi C sebanyak 12 orang $(66,7 \%)$. Setelah dilakukan uji statistik hubungan frekuensi kemoterapi dengan status gizi diperoleh nilai $p$ yaitu $0,165 \quad(p>0,05)$ sehingga dapat dikatakan bahwa tidak ada hubungan bermakna antara frekuensi kemoterapi dengan status gizi pasien kanker payudara.

Berdasarkan hasil penelitian diperoleh kelompok umur sampel yang terbanyak mengalami kanker payudara adalah pada kelompok umur 30 - 49 tahun (67,5\%). Umur sampel termuda adalah pada umur 33 tahun dan yang tertua pada umur 67 tahun. Hal ini terjadi karena menginjak umur 30 tahun sudah mulai terjadi proses penuaan pada tingkat sel, termasuk pada sel payudara. Secara anatomi dan fungsional sel payudara mengalami atropi seiring dengan bertambahnya umur. Sel-sel tersebut mengalami apoptosis yang lama sedangkan sel-sel baru terus tumbuh dan tidak terkendali didukung oleh makanan yang bersifat aterogenik. ${ }^{\mathbf{8}}$ Ignatavicius \& Workman mengungkapkan bahwa peningkatan masa hidup memungkinkan memanjangnya paparan terhadap karsinogen dan terakumulasinya berbagai perubahan genetik serta penurunan berbagai fungsi tubuh yang meningkatkan kejadian kanker pada usia>40 tahun. ${ }^{9}$

Tingkat pendidikan sampel pada penelitian ini yang terbanyak adalah pada tingkat SMA sebanyak 27 orang (67,5\%). Hal ini terjadi karena pemerataan pembangunan dan pendidikan di seluruh wilayah Indonesia.

Frekuensi kemoterapi kanker payudara yang paling banyak pada penelitian ini adalah pada kategori frekuensi kemoterapi C (frekuensi kemoterapi sama dengan atau lebih dari lima kali) yaitu sebanyak 18 sampel (45\%). Hal ini disebabkan oleh karena kebanyakan sampel yang datang sudah menjalani 
kemoterapi dengan tahapan perbaikan dan sampel berobat sudah pada stadium lanjut.

Asupan gizi sampel diketahui dengan menggunakan hasil analisa Comstock. Berdasarkan hasil penelitian diperoleh bahwa sebagian besar sampel asupan zat gizi makro yaitu asupan energi berada pada kategori kurang sebanyak 50\%, asupan protein sampel pada kategori buruk sebanyak 55\%, asupan lemak pada kategori buruk sebanyak 72,5\%, dan asupan karbohidrat pada kategori kurang sebanyak $57,5 \%$. Hal ini disebabkan oleh karena pada proses kemoterapi mempunyai efek samping yaitu terjadi mual, muntah,dan nafsu makan menurun sehingga akan mempengaruhi asupan makanan dan akhirnya akan berpengaruh pula pada asupan zat gizi. Penurunan asupan zat gizi makro ini juga kemungkinan disebabkan karena efek samping obat yang diberikan. Obat yang diberikan adalah Metotrexate dan 6-merkaptopurine. Efek samping dari kedua obat ini antara lain anoreksia, mual, muntah dan diare. Sehingga adanya efek anoreksia ini menyebabkan asupan makan pasien kanker payudara menjadi rendah. ${ }^{10}$

Keadaan ini pula yang menyebabkan asupan zat gizi mikro lebih baik daripada zat gizi makro. Di samping itu adanya kepercayaan dari sampel yang menganggap bahwa konsumsi daging dan lemak sebagai pemicu kanker sehingga sampel berusaha mengurangi konsumsi makanan tersebut. Sedangkan asupan zat gizi mikro pada penelitian ini menunjukkan sebagian besar asupan Vitamin A berada pada kategori baik sebanyak $82,5 \%$, vitamin C pada kategori baik sebanyak 65\%, sedangkan vitamin E pada kategori kurang sebanyak 52,5\%. Asupan vitamin A dan C yang baik ini disebabkan oleh adanya pemahaman dari sampel bahwa konsumsi buah dan sayur yang banyak sebagai sumber antioksidan yang dapat mengurangi dan menghambat penyebaran sel-sel kanker. ${ }^{6}$ Asupan vitamin E yang kurang pada sampel kemungkinan disebabkan oleh penggunaan bahan makanan sumber vitamin E yang masih kurang di rumah sakit. Sebagian besar sumber vitamin E terdapat pada hati dan sayuran berkecambah, sedangkan bahan makanan tersebut jarang dipergunakan di rumah sakit.

Berdasarkan hasil penelitian diperoleh bahwa status gizi sampel sebagian besar berada pada status gizi baik sebanyak 70\%. Hal ini terjadi karena perhitungan status gizi berdasarkan IMT saat ini, berat badan sampel masih stabil, dan sampel tidak mengalami komplikasi. Di samping itu adanya kecenderungan sebagian besar sampel mempunyai riwayat berat badan lebih sebelum terdiagnosa kanker, kemudian terjadi penurunan berat badan tetapi masih dalam status gizi normal berdasarkan IMT. Status gizi baik kemungkinan disebabkan asupan makanan 
di rumah lebih baik daripada asupan makanan saat di rumah sakit, karena penyediaan bahan lebih bervariasi dan sesuai dengan keinginan pasien, sedangkan sampel hanya dirawat $2-3$ hari untuk melakukan kemoterapi. Asupan zat gizi bukan satu-satunya yang menyebabkan perubahan status gizi pasien.

Setelah dilakukan uji statistik diperoleh bahwa ada hubungan yang signifikan antara frekuensi kemoterapi dengan asupan energi pasien kanker payudara, terdapat hubungan yang signifikan antara frekuensi kemoterapi dengan asupan protein pada pasien kanker payudara, tidak ada hubungan yang signifikan antara frekuensi kemoterapi dengan asupan lemak pada pasien kanker payudara dan terdapat hubungan yang signifikan antara frekuensi kemoterapi dengan asupan karbohidrat pada pasien kanker payudara.

Berdasarkan hasil penelitian dapat diketahui bahwa pada frekuensi kemoterapi C (kemoterapi sama atau lebih dari lima kali) mempunyai asupan energi yang buruk sebanyak 44,4\%, asupan protein buruk sebanyak $77,8 \%$, dan asupan lemak juga buruk sebanyak $77,8 \%$. Hal ini kemungkinan disebabkan karena pada frekuensi kemoterapi $\mathrm{C}$, sampel sudah mengalami lemas, mual, muntah, gangguan saluran cerna, sariawan, penurunan massa otot, rambut rontok, kadar $\mathrm{Hb}$ menurun dan kulit menjadi kering serta berubah warna sehingga sangat berpengaruh terhadap asupan makanannya. Frekuensi kemoterapi tidak mempunyai hubungan signifikan dengan asupan lemak terjadi karena sampel sudah mulai memilih bahan makanan yang rendah lemak akibat asumsi bahwa lemak sebagai pemicu kanker, sehingga asupan lemak dengan kategori buruk terjadi merata pada semua kategori frekuensi kemoterapi. Sedangkan frekuensi kemoterapi dengan asupan karbohidrat tidak ada hubungan, sebagian besar sampel dengan frekuensi $\mathrm{C}$ mempunyai asupan karbohidrat kurang $(83,3 \%)$. Hal ini terjadi karena pada sampel masih dapat mengkonsumsi nasi yang diberikan dari rumah sakit walaupun hanya menghabiskan setengah dari porsi yang disajikan. Akumulasi dari rendahnya asupan protein, lemak dan karbohidrat secara langsung menyebabkan asupan energi juga rendah pada sebagian besar frekuensi kemoterapi yang dijalani sampel.

Berdasarkan hasil analisia chi square menunjukkan bahwa tidak terdapat hubungan antara frekuensi kemoterapi dengan status gizi dengan nilai $\mathrm{p}$ adalah $0,165(p>0,05)$. Hasil penelitian ini berbeda dengan penelitian yang dilakukan oleh Mistirahayu yang menggunakan metode kohort. Hal ini terjadi karena status gizi sampel sebagian besar berada pada status gizi baik sebanyak $70 \%$ berdasarkan IMT saat ini, berat badan sampel masih stabil, 
dan sampel belum mengalami komplikasi. ${ }^{7}$

Sehingga walaupun sampel berada pada frekuensi kemoterapi A, B bahkan C sebagian besar status gizinya baik pada tiap kategori frekuensi kemoterapi. Meskipun sampel telah mengalami beberapa kali frekuensi kemoterapi dengan efek samping seperti mual, muntah dan gangguan saluran cerna, tetapi setelah diimbangi dengan pemberian obat anti mual maka sampel masih bisa mengkonsumsi makanan walaupun asupannya masih rendah.

\section{Simpulan dan Saran}

Tingkat asupan zat gizi makro pada sampel adalah asupan energi kurang sebanyak 50\%, asupan protein buruk sebanyak 55\%, asupan lemak buruk sebanyak $72,5 \%$, dan asupan karbohidrat kurang sebanyak 57,5\%. Tingkat asupan gizi mikro pada sampel yaitu vitamin A kategori baik sebanyak $82,5 \%$, vitamin $\mathrm{C}$ kategori baik sebanyak 65\%, dan vitamin $\mathrm{E}$ kategori kurang sebanyak 52,5\%. Status gizi sampel terbanyak status gizi baik (70\%). Frekuensi kemoterapi pada sampel berhubungan dengan penurunan asupan energi, protein dan karbohidrat sedangkan pada asupan lemak tidak ada hubungan yang bermakna. Frekuensi kemoterapi pada sampel berhubungan dengan penurunan asupan vitamin E sedangkan pada asupan vitamin $\mathrm{A}$ dan $\mathrm{C}$ tidak ada hubungan yang bermakna. Frekuensi kemoterapi tidak berhubungan secara bermakna dengan status gizi sampel.

Disarankan perlu dilakukan penelitian lanjutan tentang faktor - faktor lain yang berpengaruh terhadap asupan gizi dan status gizi pasien kanker payudara, monitoring dan evaluasi terhadap asupan makanan lebih lanjut terhadap pasien kanker payudara terutama yang sudah berada pada frekuensi kemoterapi lebih dari lima kali, penelitian tentang penurunan berat badan sebelum dan setelah kemoterapi untuk memantau terjadinya penurunan status gizi, dan melakukan edukasi untuk meningkatkan pengetahuan pasien terutama dalam pemillihan bahan makanan agar tercipta keadaan pasien yang optimal.

\section{Daftar Pustaka}

1. Jemal, A, Murray, T, Ward, E, Samuels, A, Tiwari, R.C, Ghafoor, A, Feuer, E.J, Thun, M.J. Cancer statistics, 2005.CA Cancer J Clin 2005;55:10-30.

2. Moningkey, K. 2000. Epidemiologi Kanker Payudara. Medika : Januari 2000. Jakarta.

3. RSUP Sanglah. 2013. Register Pasien Ruang Angsoka RSUP Sanglah.

4. Indonesia Protocol ALL-Standart Risk, 2006.

5. Setyaningrum, Kusti Marbawani. 2009. Hubungan Kemoterapi dengan Asupan Energi Protein dan Status Gizi pada Pasien Leukemia Limfoblastik Akut 
(LLA) di RSUP Dr. Sardjito Yogyakarta.

FK UGM. Yogyakarta.

6. Rahajeng, A.D., \& Sulchan. 2010. Tingkat Kecukupan Energi, Protein dan Status Gizi Pasien Pra dan Pasca Operasi Kanker Payudara. Skripsi. Program Studi Ilmu Gizi Fakultas Kedokteran Universitas Diponegoro. Semarang.

7. Mistirahayu, W. 2008.Pengaruh Kemoterapi terhadap Penurunan Status Nutrisi.Studi Observasional pada
Penderita Kanker di IRNA I Ruang 27 RS Dr. Saiful Anwar. Malang.

8. Weinberg. 2007. The Biology of Cancer. New York. Garland Science.

9. Ignatavicius \& Workman. 2006. Medical Surgical Nursing Critical Thingking for Collaborative Care. Vol 2. Elservier Sauder;Ohio

10. Noorwati. 2005. Kemoterapi : Manfaat dan Efek samping (internet). Jakarta: Pustaka Utama. 